\title{
Currículo, território em disputa, de Miguel Gonzáles Arroyo
}

\author{
Petrópolis, RJ: Vozes, 2011. \\ Alessandra Aparecida Dias Aguiar \\ Graduada em Pedagogia (Uninove) e em Educação Física (Fefiso); \\ Pós-graduada em Educação Física Escolar (FMU); \\ Mestranda em Educação (PROGEPE-Uninove); Coordenadora da Educação \\ Infantil na Secretaria Municipal da Educação de Jandira-SP. \\ Jandira, SP - Brasil. \\ alessandraef@bol.com.br
}

Miguel Gonzáles Arroyo é professor titular emérito da Faculdade de Educação da Universidade Federal de Minas Gerais (UFMG) e autor de diversas obras na área da educação. Em 2011, publicou Currículo, território em disputa. Pela leitura de seu trabalho, percebe-se que o autor está "mergulhado" no cotidiano escolar, pois seu texto deixa marcas significativas em quem ousa trilhar por esse território.

A partir das primeiras páginas, encontra-se um caminho possível e instigante que, ao mesmo tempo em que nos coloca diante da realidade que propõe, acaba nos envolvendo. Seu livro está organizado em cinco partes: primeira, inicia destacando os professores e seus direitos autorais nos currículos e debate a respeito das suas identidades; segunda, os saberes do trabalho docente e a disputa por um lugar nos currículos é questionada; terceira, estuda especificamente os sujeitos sociais e suas experiências na afirmação no território do conhecimento. As crianças, os adolescentes e os jovens, bem como os espaços e os direitos presentes nos currículos são apresentados na quarta e quinta; na última parte, o autor discute o direito ao conhecimento emergente nos currículos referentes à memória, à vivência dos tempos digno e justo, à cultura e à condição de cidadãos.

Indo além de seus conhecimentos experienciais em educação, Arroyo analisa o currículo de forma crítica enquanto um campo político em disputa no qual suas estruturas e ordenamentos são objeto de indagações mais do que veículo em movimento. No decorrer da obra o autor debate o currículo por meio da metáfora da corrida que envolve tempos e ritmos definidos. Ele questiona como ocorrem nas escolas as competições de corridas com pistas e ritmos preestabelecidos; pergunta quem pode entrar e participar dessa corrida do movimento dos currículos, se todo 
conhecimento tem lugar e se todos os sujeitos e suas experiências e leituras de mundo têm vez e voz em territórios tão cercados.

Continua o raciocínio dizendo que há grades que têm por função proteger o que guardam e outras que têm por função não permitir a entrada em recintos fechados; indaga, inclusive, se as grades curriculares têm cumprido essa dupla função. Questiona ao longo do texto se os currículos só protegem os conhecimentos definidos como comuns, únicos e legítimos, e acaba por negar a entrada e permanência de outros conhecimentos considerados ilegítimos e do senso comum.

Outra questão estudada por Miguel Arroyo se refere às identidades docentes: afirma que a disciplina específica na qual o professor leciona interfere na sua identidade enquanto indivíduo. A orientação do autor leva a entender que esses sujeitos estão em crise de identidade profissional, uma vez que são obrigados a seguir certa disciplina comportamental que os leva a mudar suas práticas na maneira de preparar aulas e de ensinar a matéria, desse modo sendo levados a repensar suas identidades.

O autor questiona como as políticas neoliberais e sua ênfase no treinamento, no domínio de competências, nas avaliações e classificações de alunos e mestres por resultados voltam a expatriar a educação dos seus territórios - as escolas, os currículos e a docência. Os ordenamentos curriculares que se tentam conquistar, as salas de aula e suas dinâmicas passam a ser territórios em disputa pelas concepções conservadoras, burocratizantes e, consequentemente, controladoras das inovações.

Arroyo descreve também a questão da diversidade dos sujeitos sociais que emerge em nossas sociedades, invadindo o espaço escolar, e questiona se os currículos estão abertos a essas emergências. Tantos esforços de tantos coletivos de docentes e de alunos frequentemente ficam à margem do núcleo disciplinar dos currículos, do ensino de conhecimentos; acaba não sendo central a transcrição de algo realmente acontecido, produzido por sujeitos concretos. Nesse sentido, segue trecho no qual se discute como o currículo contribui para apagar determinados rostos: "Rostos apagados, será fácil descobrir que os currículos favorecem que os rostos de alguns coletivos apareçam na história, e que os rostos de outros coletivos humanos segregados se apaguem, se percam”. (p. 262)

Questionando o que vem a constituir educação e ensino, o educador reflete a respeito de diferenças do modo pelo qual as ausências de tantos sujeitos com tantas histórias podem perder sua relevância. Ele nos alerta que, como conse- 
quência, pode ser que futuras gerações não sejam reconhecidas e que ninguém se impressione com essas desaparições.

Finaliza costurando o discurso de que o currículo na escola deve proporcionar, desde a infância, o direito ao conhecimento, às experiências, ao entendimento, à memória, à diversidade e à cultura, portanto, à formação plena.

Enfim, da leitura do livro se conclui que os escritos de Miguel Gonzáles Arroyo conformam um estudo importante e necessário sobre a temática do currículo, pois constitui uma lupa que amplia a visão e inibe o daltonismo; instiga, com outros olhos, a disputa territorial em torno do currículo, possibilitando seguir na investigação dos caminhos diversos de construção de novas perspectivas e concepções para a educação. É claro que essas são apenas algumas interpretações a respeito deste título, mas o convite está posto para embarcar na leitura de Currículo, território em disputa! 